\title{
21 \\ Reflections of a PhD student
}

\section{Benedict Scambary}

Within two weeks of arriving at the Centre for Aboriginal Economic Policy Research (CAEPR) in 2002 I found myself at a planning retreat at Charlottes Pass. As a new student of Jon Altman, I did not quite know what to expect and certainly did not know how to behave. I was a slightly angry and jaded refugee from the applied land rights and native title scene in the Northern Territory, and found myself immediately resentful of the perceived largesse of Canberra: its roads, its public buildings, its rules, its affluence, its power, its whiteness and, in particular, the number of Australian anthropologists based at ANU! What are they all doing in Canberra, I asked myself; why aren't they out in the bush?

At Charlottes Pass I learned that CAEPR was in crisis. A seven-year funding agreement with the Aboriginal and Torres Strait Islander Commission (ATSIC) had been reduced to three years. The discussion focused on the cooling of the relationship between CAEPR and ATSIC and the need to ensure that deliverables were generated and funding maintained. In my naivety I scoffed, 'what are you worried about?' The Northern Land Council (NLC) native title program, funded from the same bucket as I recall, could only secure one-year funding at best, and by the time the wheels of bureaucracy had turned, this only translated to five months' secure funding. This privileged relationship with government confused me. 
In hindsight I think I also witnessed a pivotal moment at CAEPR, and a turning point in Indigenous policy. It's not something I fully understand, but the cooling of the relationship between ATSIC and CAEPR could possibly have signalled a shift in the relationship between the academy and the state more broadly, where funded research suddenly had to be accountable to the public purse by showing its support for the political ideology of the day. If that was the beginning, then to the outside observer, it certainly seems that we are seeing an advanced stage of that now.

There is no doubt that at that point Indigenous policy was changingnative title was hotly contested by governments in every Australian jurisdiction. Cash langa finger, or 'welfare autonomy', had moved to 'sit down money', and was transforming into 'welfare poison'. Our right to take responsibility quickly morphed into shared responsibility and mutual obligation. In 2007, the Intervention crashed through the cultural museums - the neoliberal conniption of the state, wreaking havoc on the Northern Territory, placing the blame firmly on Aboriginal people for the situation they found themselves in. All bets were off, all research was out the window, everything tried before had failed, and any criticism of the approach was to sanction paedophilia. This strategy by the state had the remarkable effect, it seems, of disarming the academy. The critique appeared to come from just a few, and Jon Altman was at the forefront.

During my time at CAEPR I witnessed the prodigious response of the organisation to these policy shifts under Jon's stewardship. The response was always reasoned, evidence-based, and exploratory in a way that sought to highlight the positives and negatives of an approach - to give credit where it was due, and to provide criticism where it was due. CAEPR engaged in rigorous, often multidisciplinary, research that could only be described as being in the public good. The ethos of the research appeared to me to be based on notions of equality, pragmatism, and fiscal responsibility.

These rapid shifts in Indigenous policy gave little time for reflection on the part of the policymakers and politicians. CAEPR research appeared to be uncomfortably ignored in favour of research based more on ideology than evidence. As the gulf between policy and the policy research of CAEPR widened, it seemed to me that Jon increasingly sought to use the media to get his message across. His research also 
became more action oriented, though arguably it always was. At the conference that led to this volume we heard of the influence of Jon's and CAEPR's research in the inclusion of aspects of cultural production in the first National Aboriginal and Torres Strait Islander Survey, the programs employing rangers in environmental services, the establishment of the Indigenous Governance Awards, and the Community Development Employment Projects (CDEP) scheme, to name a few. I would also add that CAEPR research on mining is acknowledged as being a key influence on RioTinto's \$2 billion mining agreement in the Pilbara. In rebutting Nicolas Peterson, Jon succinctly describes the hybrid economy as a question, a model for talking to Aboriginal people to apply pushback on the relentless neoliberal project and a question that addresses the global issue of surplus labour (Altman, this volume).

Incredibly, Jon has managed to be responsive to policy shifts and an integral commentator on Indigenous policy for decades. Examples include responses to John Hewson's Fightback!, changes to CDEP, and the Northern Territory Intervention. While Jon has been characterised as a critic of government policy, I would argue that he has been frank and fearless through examination and analysis of the evidence available. While his opinion may differ from the status quo, he maintains a level of integrity in his scholarship that is true to his own values of fairness and equality.

Often Jon's commentary has been perceived as overly critical of new government initiatives, too idealistic and therefore too hard to warrant incorporation into mainstream policy initiatives. The level of retort undoubtedly reflects the level of discomfort that his critique creates for an often lazy, unimaginative and ill-informed bureaucracy, and let's not forget the politicians.

But it is this discomfort-sometimes annoyance - engendered in the debate around Indigenous policy that is in many ways the fundamental value of Jon's research. He seeks to hold accountable the bureaucrats, politicians and commentators who all too readily retreat to ideology as a basis for justifying and implementing punitive and disruptive policy initiatives - initiatives that ignore the reality of people's lives, that ignore the evidence of research, that favour market interests over those of the most disadvantaged. In arguing against the Intervention, Stronger Futures, and those who seek to portray 
Indigenous disadvantage as resulting from the cultural prerogatives and choices of Aboriginal people, Jon has consistently highlighted the historic underspend on Indigenous citizenship rights. He takes issue with policy initiatives that grossly misrepresent the scale of the problem they are designed to address and consistently underestimate the resources required.

Nic Peterson (this volume) states that government and policymakers 'do not have the luxury of doing nothing', but it is apparent, as Peter Cooke has highlighted, that they do have the luxury to make an awful hash of doing something. ${ }^{1}$ That is what is happening at the moment. In the Northern Territory as politicians call for the 'patriation of the Land Rights Act' to the Territory (because Canberra is too far away), policymakers are scrambling to reverse engineer the justification. Reforms in Aboriginal land tenure are placing a complex of leases and subleases on Aboriginal land so that the conditions for private home ownership can be created. This is being hailed a success, with 11 enquiries received from people at Gunbalanya, Yirrkala, Groote Eylandt and the Tiwi Islands. A matrix of stratification to assess the willingness of 'remote communities' to opt in or out is being applied to redirect government services in a way that is not too far removed from the limitations Nicolas Peterson (this volume) identifies of 'desirable long term dependencies'.

In returning to Canberra in 2014 for the Engaging Indigenous Economy Conference, I had a different perspective than back in 2002. Thanks to Jon, I have a better understanding of the power of research, and its relationship to power. The conference and this volume have highlighted the impacts of Jon Altman's research on Indigenous policy and academic thinking. But it is clear that Jon's research influence reaches beyond policy development and into the realm of empowerment of Aboriginal people, and that he has achieved an enormous amount in this regard. His research is frank and fearless, and is of its nature political. The academy still occupies a position of privilege, and to Jon's credit he has used that privilege to speak truth to power.

1 Peter Cooke spoke at the Engaging Indigenous Economy Conference as part of Cooke P, Garde M, Guymala T \& Yibarbuk D (2014). Contemporary customary economy, attribution of value and the management of Warddeken Indigenous Protected Area, presentation at Engaging Indigenous Economy Conference: Debating Diverse Approaches, The Australian National University, Canberra, 4 September. 


\section{References}

Cooke P, Garde M, Guymala T \& Yibarbuk D (2014). Contemporary customary economy, attribution of value and the management of Warddeken Indigenous Protected Area, presentation at Engaging Indigenous economy conference: debating diverse approaches, The Australian National University, Canberra, 4 September. 
This text is taken from Engaging Indigenous Economy: Debating diverse approaches, edited by Will Sanders, published 2016 by ANU Press, The Australian National University, Canberra, Australia. 